\title{
Improvements to the OMI near-UV aerosol algorithm using A-train CALIOP and AIRS observations
}

\author{
O. Torres ${ }^{1}$, C. Ahn ${ }^{2}$, and Z. Chen ${ }^{2}$ \\ ${ }^{1}$ NASA Goddard Space Flight Center, Greenbelt, Maryland, 20771, USA \\ ${ }^{2}$ Science Systems and Applications, Inc., Lanham, Maryland, 20706, USA \\ Correspondence to: O. Torres (omar.o.torres@nasa.gov)
}

Received: 19 April 2013 - Published in Atmos. Meas. Tech. Discuss.: 21 June 2013

Revised: 7 October 2013 - Accepted: 14 October 2013 - Published: 27 November 2013

\begin{abstract}
The height of desert dust and carbonaceous aerosols layers and, to a lesser extent, the difficulty in determining the predominant size mode of these absorbing aerosol types, are sources of uncertainty in the retrieval of aerosol properties from near-UV satellite observations. The availability of independent, near-simultaneous measurements of aerosol layer height, and aerosol-type related parameters derived from observations by other A-train sensors, makes possible the use of this information as input to the OMI (ozone monitoring instrument) near-UV aerosol retrieval algorithm (OMAERUV). A monthly climatology of aerosol layer height derived from observations by the CALIOP (Cloud-Aerosol Lidar with Orthogonal Polarization) sensor, and real-time AIRS (Atmospheric Infrared Sounder) carbon monoxide $(\mathrm{CO})$ observations are used in an upgraded version of the OMAERUV algorithm. AIRS CO measurements are used as an adequate tracer of carbonaceous aerosols, which allows the identification of smoke layers in regions and seasons when the dust-smoke differentiation is difficult in the near-UV. The use of CO measurements also enables the identification of high levels of boundary layer pollution undetectable by near-UV observations alone. In this paper we discuss the combined use of OMI, CALIOP and AIRS observations for the characterization of aerosol properties, and show an improvement in OMI aerosol retrieval capabilities.
\end{abstract}

\section{Introduction}

Since the discovery of the near-UV capability of absorbing aerosols detection from space over a decade ago (Hsu et al., 1996; Herman et al., 1997; Torres et al., 1998), the
UV Aerosol Index (AI), calculated from observations by the Total Ozone Mapping Spectrometer (TOMS) family of sensors, and more recently by the Ozone Monitoring Instrument (OMI), has been used to map the daily global distribution of UV-absorbing aerosols such as desert dust particles as well as carbonaceous aerosols generated by anthropogenic biomass burning and wildfires (Herman et al., 1997), and volcanic ash injected in the atmosphere by volcanic eruptions (Seftor et al., 1999). The AI concept for aerosol detection has also been applied to other near-UV capable sensors such as GOME (Gleason et al., 1998; De Graaf et al., 2005a), and SCIAMACHY (de Vries et al., 2009; De Graaf et al., 2005b).

In addition to the qualitative AI product, near-UV retrieval algorithms of aerosol extinction optical depth (AOD) and single scattering albedo (SSA) making use satellite measurement in the 330-388 $\mathrm{nm}$ range have been applied to the TOMS (Torres et al., 1998, 2002) and OMI (Torres et al., 2007; Ahn et al., 2008) observations. The quantitative interpretation of the near-UV measurements in terms of aerosol absorption, however, is affected by the dependency of the measured radiances on the height of the absorbing aerosol layer (Torres et al., 1998; De Graaf et al., 2005a), and the difficulty in differentiating between carbonaceous and desert dust aerosol types, especially over land.

In the absence of direct observations to diagnose the location of the aerosol layer in the atmosphere, the TOMS aerosol algorithm (Torres et al., 2002) used a transport model generated climatology of aerosol layer height (Ginoux et al., 2001). To differentiate between absorbing aerosol types (carbonaceous or desert dust), the TOMS algorithm used geographical location and surface type considerations (Torres et al., 2002). 
The near-simultaneity of satellite observations by a plurality of A-train sensors, provides the unprecedented opportunity of combining time- and space-collocated radiance observations and/or derived atmospheric parameters for global climate analysis (Anderson et al., 2005). Combined A-train observations can also be used in inversion algorithms to further constrain retrieval conditions and, thus, reduce the need for assumptions. CALIOP (Cloud-Aerosol Lidar with Orthogonal Polarization) measurements of the vertical distribution of the atmospheric aerosol load, and Atmospheric Infrared Sounder (AIRS) carbon monoxide (a suitable tracer of carbonaceous aerosols) observations, provide information that can be used to prescribe aerosol layer height and determine aerosol type in the OMI near-UV aerosol algorithm (OMAERUV).

In this paper we discuss the use of observations by A-train sensors CALIOP and AIRS, on aerosol layer height and CO to provide reliable information on aerosol layer height and aerosol type as input to OMAERUV. In Sect. 2, we briefly describe an improved version of the OMAERUV algorithm that utilizes CALIOP and AIRS observations as ancillary information. A detailed description of the way AIRS CO data is used in the OMI aerosol inversion procedure is presented in Sect. 3, followed by a discussion of the development of a CALIOP-based aerosol layer height climatology in Sect. 4, and an evaluation of the improved accuracy of OMI retrievals using AERONET observations in Sect. 5. Summary and final remarks are presented in Sect. 6.

\section{The OMAERUV algorithm}

OMI is a spectrograph that measures upwelling radiances at the top of the atmosphere in the range $270-500 \mathrm{~nm}$ (Levelt et al., 2006) since its deployment in 2004 . With a $2600 \mathrm{~km}$ across-track swath, and sixty viewing positions, it provided nearly daily global coverage at a $13 \times 24 \mathrm{~km}$ nadir resolution $(28 \times 150$ at extreme off-nadir) during the first three years of operation. Since mid-2007, an external obstruction to the sensor's field of view, perturbing OMI measurements of both solar flux and Earth shine radiance at all wavelengths, began to progressively develop. Currently, about half the sensor's sixty viewing positions are affected by what is referred to as "row anomaly", since the viewing positions are associated with the row numbers on the CCD detectors. The site http://www.knmi.nl/omi/research/product/ rowanomaly-background.php provides details on the onset and progression of the row anomaly.

The OMAERUV algorithm uses as input measured reflectances at 354 and $388 \mathrm{~nm}$ to retrieve column atmosphere values of AOD and single SSA. Ancillary information on near-UV (354 and $388 \mathrm{~nm}$ ) surface albedo $\left(A_{\lambda}\right)$, scene type, and aerosol layer height (ALH) is required. Values of surface albedo are obtained from a TOMS-based long-term climatology of minimum reflectivity similar to that of Herman and Celarier (1997), modified to account for the darkening effect of strongly absorbing aerosols. Real-time AIRS CO measurements are used to identify carbonaceous particles, and ALH is inferred based on CALIOP measurements. The ways AIRS CO and CALIOP aerosol height information are used in the OMAERUV algorithm is the central theme of this paper, and it is discussed at length in Sects. 3 and 4.

\subsection{Aerosol models and forward calculations}

The algorithm assumes that the atmospheric aerosol column can be represented by one of three aerosol types: desert dust (DD), carbonaceous particles (CB), and sulfate-based (SF) aerosols. Each aerosol type is characterized by a fixed bimodal spherical particle size distribution (Torres et al., 2007) with parameters derived from long-term AERONET statistics (Dubovik et al., 2002). The relative spectral dependence of the imaginary component of refractive in the $354-388 \mathrm{~nm}$ range, $\Delta k$, is assumed for each aerosol type (Torres et al., 2007), and has been recently modified for the CB type to account for the absorption effects of organic carbon (Jethva and Torres, 2011). Each aerosol type is further divided into seven sub-types to account for the variability of the imaginary component of the refractive index at $388 \mathrm{~nm}, k_{388}$, which, in combination with the assumed size distribution, translates into SSA variability.

Forward radiative transfer calculations of upwelling reflectance at the top of the atmosphere ( 354 and $388 \mathrm{~nm}$ ) for the resulting 21 aerosol models were used to generate a set of look-up tables (LUTs) with nodal points in viewing geometry, AOD, SSA, ALH.

\subsection{Inversion procedure}

The measured reflectances are first used to calculate the scene $388 \mathrm{~nm}$ Lambert Equivalent Reflectivity $\left(R_{388}\right)$, and the absorbing Aerosol Index (AI) as described in Torres et al. (2007). Different algorithms are applied over the oceans and the continents. Because of the difficulty associated with the separation of ocean color effects from those of low aerosol concentrations, retrievals over the oceans are performed only when absorbing aerosols are present (either DD or CB types ) in sufficient amounts as indicated by AI values larger than (or equal to) 0.8. Retrievals over land, on the other hand, are carried out under all conditions regardless of the value of AI. Figure 1 shows a schematic overview of OMAERUV's retrieval procedure. In addition to Aerosol Index and carbon monoxide data, scene type from the International Geosphere/Biosphere Programme (IGBP) database (Loveland et al., 2000) (http://www-surf.larc.nasa.gov/surf/ pages/data-page.html) are used at each OMI pixel to select an aerosol type (see top left box in Fig. 1). For easy handling, we define the dimensionless parameter $\mathrm{COI}(\mathrm{CO}$ in$\mathrm{dex}$ ) as the column $\mathrm{CO}$ amount (in molecule $\mathrm{cm}^{-2}$ ) divided by $10^{18}$ molecules $\mathrm{cm}^{-2}$. 


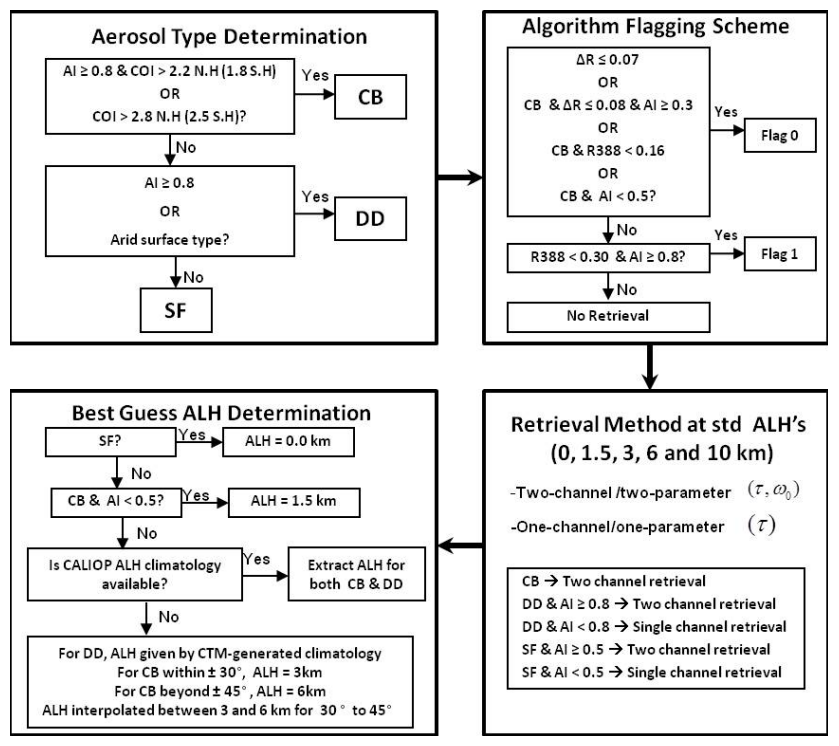

Fig. 1. Graphic description of OMAERUV inversion scheme.

The absorbing aerosol type identification is achieved by examining the values of $\mathrm{AI}$ and $\mathrm{COI}$ in relation to threshold values $\mathrm{AI}_{0}$ and $\mathrm{COI}_{0}$ that represent, respectively, $\mathrm{AI}$ noise and background COI values not necessarily associated with the free troposphere $\mathrm{CO}$ burden which is expected to co-exist with the lofted carbonaceous aerosols (Andreae and Metlet, 2001). Adopted threshold values of $\mathrm{COI}_{0}$ correspond to the average of AIRS CO climatological annual minima over major biomass-burning/boreal fire activity regions. Such values are 2.2 in the Northern Hemisphere and 1.8 for the Southern Hemisphere, based on Yurganov et al. $(2008,2010)$. The value of $\mathrm{AI}_{0}$ ( 0.8 for both land and ocean conditions), is a slightly smaller value that the one used in the interpretation of TOMS AI data (Herman et al., 1997). The presence of carbonaceous aerosols is assumed if $\mathrm{AI} \geq \mathrm{AI}_{0}$, and $\mathrm{COI} \geq$ $\mathrm{COI}_{0}$ when $\mathrm{COI}$ values larger than 2.8 (2.5) are observed in the Northern (Southern) Hemisphere regardless of AI considerations. Pixels failing the CB test are deemed to be dominated by $\mathrm{DD}$ aerosols if either the condition $\mathrm{AI} \geq \mathrm{AI}_{0}$ and $\mathrm{COI}<\mathrm{COI}_{0}$ is met, or the underlying scene type corresponds to the arid category (Loveland et al., 2000). Otherwise, the presence of sulfate aerosols is presumed over land. No retrieval takes place over the ocean.

Because of the large OMI footprint, standard spatial homogeneity techniques of detecting sub-pixel cloud contamination are impractical. In the OMAERUV algorithm, an attempt to identify and exclude cloud-contaminated scenes is done on a pixel-by-pixel basis making use of AI, the calculated scene reflectivity $\left(R_{388}\right)$, the difference $R_{388}-A_{388}$, $(\Delta R)$, and the selected aerosol type. The difference $\Delta R$ is an upper limit in the allowed aerosol-related reflectivity above the value of the surface reflectance $A_{388}$. The default $\Delta R$ value (0.07) applies to both DD and SF aerosol types. In the presence of $\mathrm{CB}$ aerosols, the cloud contamination criteria is relaxed to allow for the detection of very large AOD values typical of carbonaceous aerosols resulting from biomass burning and wildfires. Additional considerations on $R_{388}$ and AI are applied to those pixels with COI values larger than 2.8 (2.5) in the Northern (Southern) Hemisphere as illustrated in the top right box of Fig. 1. An algorithm flagging scheme assigns confidence levels on the occurrence of cloud-free conditions by means of an algorithm quality flag (QF) whose value is 0 for minimum cloud presence, and has a value of 1 when it is suspected that the retrieval product is affected by cloud contamination.

Two retrieval approaches are used depending on the nature of the aerosol signal: a two-channel inversion method that allows the simultaneous retrieval of AOD and SSA, and a single-channel retrieval of AOD in which a SSA of 1.0 is assumed. The two-channel method is always applied over the oceans. Over land, however, the actual retrieval method depends on the magnitude of the AI and aerosol type. The twochannel retrieval is applied for the CB aerosol type, regardless of the value of AI . The same approach is applied for DD aerosols and AI values larger than (or equal to) 0.8 , or for SF aerosols and AI values larger than (or equal to) 0.5. For DD aerosols and AI less than 0.8, and for SF aerosols and AI less than 0.5 the single-channel method is applied. These AI threshold values are the result of a trial-and-error approach to optimize algorithm's performance. Retrievals results are obtained for the five ALH nodal points in the LUTs (surface, $1.5,3,6$, and $10 \mathrm{~km})$.

A best-guess ALH must be prescribed as the accuracy of the satellite-retrieved properties of absorbing aerosol types in the near UV, is highly sensitive to the aerosol layer altitude above the ground (Torres et al., 1998). The lower left diagram of Fig. 1 describes the steps for ALH determination. For the SF aerosol type, a vertically decaying distribution is used, in which aerosol concentration is largest at the surface and decreases exponentially with height. If either the DD or $\mathrm{CB}$ aerosol type has been selected, the best guess ALH is given by a CALIOP-based climatological value $\left(Z_{\text {clp }}\right)$ developed for this purpose, and discussed in detail in Sect. 4. If the CALIOP climatology does not provide an ALH entry, an ALH assumption is made that depends on aerosol type and location as shown in Fig. 1. Carbonaceous aerosols layers within $30^{\circ}$ of the Equator are assumed to have maximum concentration at $3 \mathrm{~km}$ above the surface whereas mid- and high-latitude (polewards of $\pm 45^{\circ}$ ) smoke layers are assumed to peak at $6 \mathrm{~km}$. The height of smoke layers between $30^{\circ}$ and $45^{\circ}$ latitude in both hemispheres is interpolated with latitude between 3 and $6 \mathrm{~km}$. The location of desert dust aerosol layers varies between 1.5 and $10 \mathrm{~km}$, and is given by a multiyear climatological average of Chemical Model Transport (CTM) calculations using the GOCART model (Ginoux et al., 2001) gridded at a resolution of $2.5^{\circ}$. Thus, in addition to retrievals at five standard ALH values, a retrieval at the best-guess value of ALH is also reported. 


\section{Combined use of OMI-AI and AIRS-CO for aerosol type identification}

In the near-UV, the separation between absorbing and nonabsorbing aerosol types is straightforward given the large sensitivity to aerosol absorption in this spectral region (Torres et al., 1998; Penning de Vries et al., 2009). Differentiating between carbonaceous (fine particles) and dust (coarse particles), aerosols in ocean satellite retrieval algorithms that use visible and near IR observations, is generally done in terms of the well-known Ångström's wavelength exponent (AE) (Angstrom, 1929), whose magnitude is inversely related to the predominant particle size. Typical AE values vary from nearly zero for high concentrations of desert dust aerosols to values of 2.0 or greater associated with large AOD finesize carbonaceous aerosols (Eck et al., 1999; Toledano et al., 2011). Satellite-derived AE for aerosol type differentiation over land is unreliable due to uncertainties associated with surface reflectance characterization (Levy et al., 2010). Because of the short separation of the two channels in the OMAERUV algorithm, the AE concept is not applicable and, therefore, distinguishing between fine and coarse size mode absorbing aerosol types (i.e., carbonaceous versus desert dust aerosols) requires additional external information. Although OMI reflectance measurements up to $500 \mathrm{~nm}$ are available, their use in AE calculation requires a precise characterization of visible surface albedo currently unavailable.

\subsection{Carbonaceous aerosols tracers}

Numerous trace gas species are released into the atmosphere during biomass burning and wildfire episodes that also produce large amounts of carbonaceous aerosols. Thus, depending on their lifetime and availability of measurements, some of these chemical compounds could serve as tracers of the atmospheric load of carbonaceous aerosol. Nitrogen dioxide $\left(\mathrm{NO}_{2}\right)$ and formaldehyde $\left(\mathrm{CH}_{2} \mathrm{O}\right)$ are important biomassburning byproducts (Yokelson et al., 2003) which are measured by OMI and could, in principle, be conveniently used as carbonaceous aerosol tracers. Because of their relative short lifetimes (only up to a few hours), however, these trace gases are not adequate for tracing the long-range aerosol transport. Carbon monoxide (CO), on the other hand, is the second most abundant trace gas produced by biomass burning (Andreae and Merlet, 2001; Sinha et al., 2003), and has a multiday-long lifetime that makes it a suitable tracer of longrange transport carbonaceous aerosols. Atmospheric $\mathrm{CO}$ and carbonaceous aerosols concentrations in the free troposphere have been found by airborne (Andreae et al, 1994), and satellite observations to be highly correlated. A multi-year analysis of MODIS aerosol optical depth and MOPPIT CO column amounts (Edwards et al., 2004) revealed that in the case of agriculture-related biomass burning and wildfires, a high correlation between the satellite measurements was consistently observed. An analysis in the Southern Hemi- sphere documented and quantified the clear high correlation between CO column amounts and fine size AOD MODIS measurements in biomass-burning environments (Edwards et al., 2006). No correlation between AOD and CO concentrations was observed for other aerosol types. A correlative analysis of air-quality-related measurements during 2010 in Moscow also shows MODIS AOD and OMI Aerosol Index to be highly correlated with AIRS CO column amounts (Witte et al., 2011). Luo et al. (2010) also found a clear spatial correlation between tropospheric emission spectrometer (TES) $\mathrm{CO}$ measurements and the OMI Aerosol Index signal of the smoke plume generated by the 2006 Australian fires (Torres et al., 2007; Dirksen et al., 2009). Satellite global daily CO measurements are routinely produced by the Measurements of Pollution in the Troposphere (MOPITT) sensor on the Terra satellite (Pan et al., 1998) and by the Atmospheric Infrared Sounder (AIRS) on the Aqua platform (Aumann et al., 2003). Because of the near-simultaneity of AIRS and OMI observations, the AIRS CO product is used in this analysis.

\subsection{The AIRS CO product}

The AIRS sensor was deployed on 4 May 2002. It is a cross-track scanning grating spectrometer that measures IR radiation at 2378 channels between 3.7 and $16 \mu \mathrm{m}$ with a $13.5 \mathrm{~km}$ nadir field of view (Aumann et al., 2003). AIRS' $\mathrm{CO}$ inversion uses radiances in the $4.50-4.58 \mu \mathrm{m}$ region. It is considered a robust retrieval because of its strong spectral signature and weak water vapor interference with an estimated accuracy of about $15 \%$ (McMillan et al., 2005). Highest sensitivity is reported at about $500 \mathrm{mb}(\sim 5.5 \mathrm{~km})$. The sensitivity is enhanced for high CO levels associated with biomass burning. In general, AIRS CO averaging kernel in the presence of smoke plumes allows detection between about 800 to $500 \mathrm{mb}(\sim 2.0$ to $5.5 \mathrm{~km})$ (McMillan et al., 2005). The use of cloud-clearing (Chahine et al., 1974) allows for the retrievals of global $\mathrm{CO}$ for conditions up to $80 \%$ cloudy (Susskind et al, 2003). In this analysis we used the global daily gridded AIRS column $\mathrm{CO}$ product expressed as molecules $\mathrm{cm}^{-2}$ at a $1^{\circ} \times 1^{\circ}$ resolution, available at http://daac.gsfc.nasa.gov/AIRS.

\subsection{Combined use of $\mathrm{CO}$ and $\mathrm{AI}$ observations}

The spatial distributions and magnitudes of tropospheric $\mathrm{CO}$ amounts and atmospheric load of carbonaceous aerosols are naturally correlated as both species are generated by biomass burning. On the other hand, no correlation is expected to exist between tropospheric $\mathrm{CO}$ and the atmospheric aerosol burden associated with desert dust particles. An example of the expected relationship between $\mathrm{CO}$ and dust and smoke aerosols in shown in Fig. 2. The top panel shows the global spatial distribution of the OMI AI on 7 July 2006. The AI map shows pools of large AI values over southeastern Canada and eastern US possibly associated with an 
advancing smoke layer generated by boreal fires in Canada. Another large absorbing aerosol plume lingers over equatorial Africa between the Equator and about $10^{\circ} \mathrm{S}$, most likely the result of agriculture-related burning practices. Large AI values are also present over the arid areas of North Africa, the Arabian Peninsula, and Central Asia, as well as over the Atlantic Ocean, indicating the presence of a drifting synoptic scale desert dust plume. The center panel in Fig. 2 shows the AIRS-CO column amount as derived from AIRS observations on the same day. Note that very large values of $\mathrm{CO}$ column amounts are observed over the areas dominated by the presence of smoke but not over the large regions occupied by the desert dust layers. The combined use of the AI and COI (as defined in Sect. 2) parameters allows for the separation of smoke/dust plumes as shown on the bottom panel of Fig. 2.

Although this straightforward way of separating absorbing aerosol types works very well in most cases, it may break down under certain circumstances. A notable case when the approach fails takes place when dust aerosols are present over a region characterized by high $\mathrm{CO}$ levels associated with pollution episodes other than smoke. In this case the above-described approach will identify the absorbing aerosol type as smoke. This situation is likely to happen over eastern China during the spring season when the normally high $\mathrm{CO}$ levels co-exist with the westerly flow of large amounts of desert dust aerosols from the Gobi and Taklimakan deserts. A similar situation is likely to happen in the presence of smokedust mixtures which in turn is likely to happen in NE China and the Sahel regions. If CO levels are high enough, the CB aerosol type will be selected since the retrieval algorithm does not allow for aerosol type mixtures.

The CO-based aerosol type separation technique is particularly useful to pick up the presence of drifting layers of carbonaceous aerosols over arid areas. One such event took place on 27 August 2007 when the smoke plume of the fires in Greece (Turquety et al., 2009) moved south across the Mediterranean, reaching Northern Libya and Algeria. Figure 3 displays the AI and $\mathrm{CO}$ fields over Africa as derived from OMI and AIRS observations on this day. The AI map (left) shows three prominent aerosol features with AI values between three and five times the background $(\sim 0.6)$.

The first is a narrow arc-shaped aerosol feature with AI values larger than 2.2 extending from southern Greece across the Mediterranean and reaching northeast Libya, it then goes across northern Libya, Tunisia and Algeria, advances northward back to the western Mediterranean. A region of enhanced $\mathrm{CO}\left(1.8 \times 10^{10} \mathrm{~mol} \mathrm{~cm}^{-2}\right.$ and higher $)$ is observed in North Africa over most of Egypt, Libya, and Algeria. The core of the $\mathrm{CO}$ plume (CO values $\sim 2.4 \times 10^{10} \mathrm{~mol} \mathrm{~cm}^{-2}$ and higher) looks remarkably similar in shape and geographical extent to the aerosol feature in the AI map. Both the $\mathrm{AI}$ and $\mathrm{CO}$ signatures allow tracing the plume all the way back to what appears to be its origin in southern Greece. The combined use of these quantities in the aforementioned man-
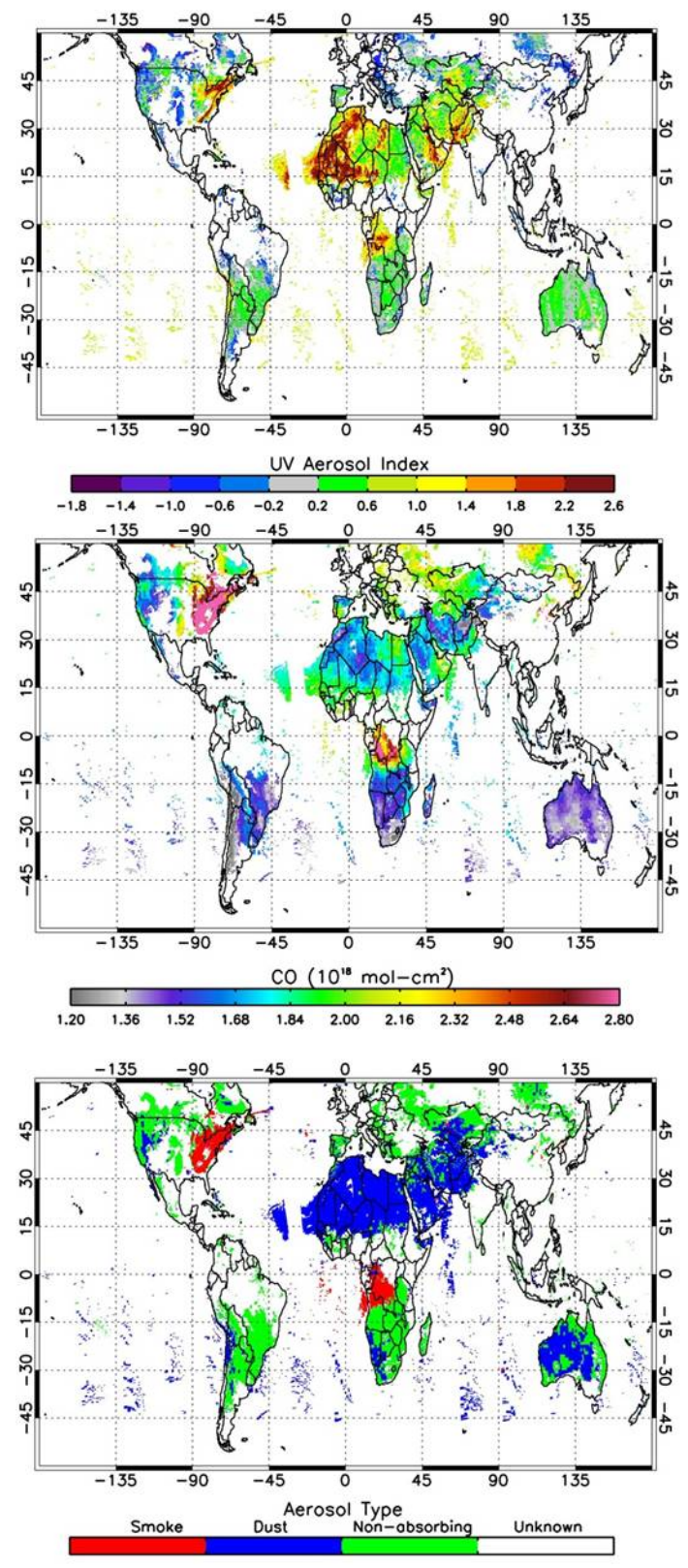

Fig. 2. OMAERUV Aerosol Index on 7 July 2006 (top), AIRS CO amounts (middle), and aerosol type classification (bottom).

ner, allows for the identification of the carbonaceous aerosol plume shown on the right panel of Fig. 3. It should be noted that the actual $\mathrm{CO}$ feature is more spatially extended than the AI plume, indicating the transport of $\mathrm{CO}$ molecules (but not aerosol particles) beyond the plume's core.

A second prominent aerosol event with AI values larger than 2.0 is clearly observed over northwest Africa over Mali, Mauritania, and southern Algeria. The CO map shows no enhanced $\mathrm{CO}$ values over the same region. The lack of spatial correlation between the aerosol load and $\mathrm{CO}$ over the region suggests the presence of dust aerosols. 


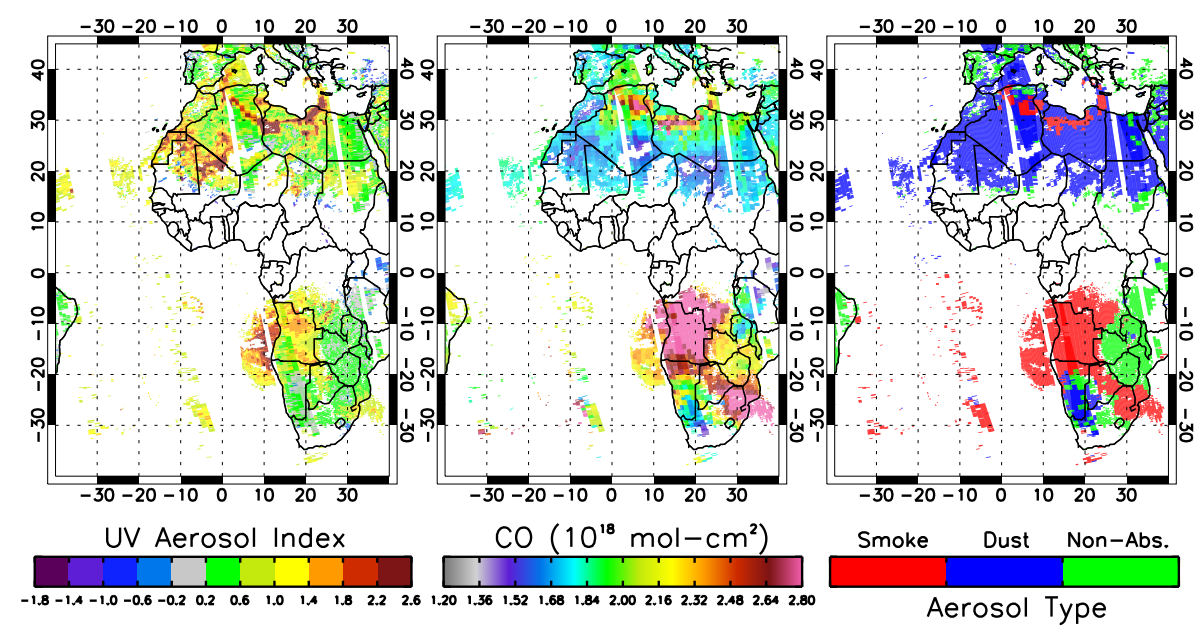

Fig. 3. Aerosol type determination over Africa on 27 August 2007 (see text for details).

The third aerosol feature with AI values larger than 1.0 is present in Southern Africa over parts of Angola, Congo, and Botswana. Enhanced CO levels are reported by AIRS CO measurements over the same region, suggesting the presence of carbonaceous aerosols. The aerosol type map in Fig. 3, obtained by the previously described method, shows the unmistakable presence of the Greek fires smoke plume over North Africa.

\subsection{Boundary layer pollution aerosols}

CO measurements are also used in the OMAERUV algorithm to identify cases of high amounts of carbonaceous aerosols in the boundary layer that would otherwise go undetected by the AI which is sensitive to elevated aerosols. Large summer AOD values are reported by AERONET observations in rapidly developing industrial regions of the world such as northeastern China and northern India. Because of their low elevation, these aerosols yield AI values below the reliability limit $(\sim 0.8)$ in the near UV. In addition, because of their extraordinarily large concentrations they were often mistaken as cloud contamination in earlier versions of the algorithm. Correlative analysis of ground-based AOD measurements and satellite CO measurements (not shown) indicate high correlation between the two parameters. Based on this analysis OMAERUV retrievals are now carried out when the measured $\mathrm{CO}$ values are larger than $2.8 \mathrm{E} 18(\mathrm{NH})$ or 2.5E18 $(\mathrm{SH})$ regardless of the AI value.

\section{Combined use of OMI and CALIOP observations}

CALIOP is a three-channel lidar on board the CALIPSO platform launched in 28 April 2006 in an ascending polar orbit with a $1: 32 \pm$ Equator crossing time. It measures polarization-insensitive attenuated backscatter at 532 and $1064 \mathrm{~nm}$ during both day- and nighttime. In addi- tion, CALIOP measures polarization sensitive backscatter at $532 \mathrm{~nm}$. CALIOP probes the atmosphere between the surface and $40 \mathrm{~km}$ above sea level at a vertical resolution that varies between 30 and $60 \mathrm{~m}$. The horizontal resolution along the orbital track is $335 \mathrm{~m}$ (Winker et al., 2003). CALIOP data has been available since mid-June 2006 and, except for minor interruptions, continues to be available. In addition to the attenuated backscatter profile data, CALIOP's aerosol products include a vertical feature mask that characterizes particle layers as either cloud or any of several aerosol types, and an aerosol optical depth product. In this study we use daytime observations of the $1064 \mathrm{~nm}$ attenuated backscatter. Unlike AIRS global daily coverage, CALIOP's narrow $335 \mathrm{~m}$ footprint does not allow the direct use of daily observations, as no global coverage is available. Therefore, developing a climatological data set is the best way to make use of CALIOPprovided aerosol layer height data.

\subsection{Collocation}

The OMI sensor makes observations at sixty positions (or viewing angles) across the orbital track. Positions 30 and 31 are closest to nadir. At launch, CALIPSO's sub-satellite point coincided with OMI's scan position 45 on the right side of the OMI scan for most of the orbit at low and mid-latitudes, and the time difference between OMI and CALIOP daytime observations was about $13 \mathrm{~min}$. As the Aura satellite orbit was changed to reduce the overpass time difference with that of Aqua, the OMI scan position of coincidence with CALIOP's observations changed to 37 over several months, and by the end of the orbital maneuver the time observation difference between CALIOP and OMI decreased to about 8 min.

At CALIOP's $335 \mathrm{~m}$ horizontal resolution, there are 39 CALIOP profiles of attenuated backscatter per OMICALIOP collocation pixel (OCCP) along CALIPSO's orbital track. In this work we use a specially created set of orbital 
files that contain merged OMI and CALIOP data collocated along CALIPSO's orbital track. The OMI level 2 data subset coincident with CALIOP's measurements was produced by the A-Train Data Depot (ATDD) project at the Goddard Earth Sciences Data and Information Services Center to address the differences in spatial, vertical, and horizontal, as well as temporal scales of coverage of different instruments participating in the A-Train (Savtchenko et al., 2008). The ATDD data set was augmented with CALIOP's observations of attenuated backscatter at 532 and $1064 \mathrm{~nm}$. In addition to the CALIOP backscatter data and ancillary information, the merged orbital files contain OMI-measured radiances, viewing geometry, ancillary data and original retrieval results at the OCCP plus four additional OMI pixels on each side of the OCCP for a total of 9 pixels. This collocated data set was also used in a comparative analysis of OMI and CALIOP aerosol products (Chen et al., 2012).

\subsection{Cloud screening}

The available CALIOP backscatter profiles per OCCP were combined to create an average profile representative of the vertical distribution of the atmospheric load of carbonaceous and/or desert dust aerosols over the OCCP. An attempt to minimize the effect of cloud contamination on both observations was carried out by applying cloud screening procedures to both OMI and CALIOP observations. Heavily cloud-contaminated OMI data was excluded by rejecting observations where the OCCP-derived Lambert-equivalent reflectivity (LER) was larger than $25 \%$. The calculated average CALIOP profiles were screened for the presence of clouds by excluding those layers where the resulting average backscatter was larger than 0.005 . The effect of noise was also excluded by rejecting layers where average backscatter was smaller than 0.0015. A comparison of CALIOP backscatter profiles at 532 and $1064 \mathrm{~nm}$ revealed what appears to be a loss of sensitivity due to attenuation of the $532 \mathrm{~nm}$ measurement in the presence of carbonaceous aerosols. Figure 4 (left panel) shows the average of nearly 6000 CALIOP-attenuated backscatter profiles at $532 \mathrm{~nm}$ (solid line) and $1064 \mathrm{~nm}$ (dotted line) associated with a carbonaceous aerosol layer in South America on 30 September 2007. The shapes of the backscatter profiles are markedly different for the two wavelengths, with the $532 \mathrm{~nm}$ measurement showing an apparent decreased sensitivity to aerosol presence near the surface. The right panel of Fig. 4 illustrates a similar average of nearly 1800 profiles depicting the backscatter profiles of a desert dust layer in North Africa on 12 August 2006. In this case, the profile shapes given by the two measurements are quite similar, suggesting that the sensitivity loss observed on the left panel may be related to the aerosol type. Further analyses (not shown) indicate that the occurrence of these anomalous $532 \mathrm{~nm}$ profiles is consistently associated with the presence of carbonaceous aerosols over regions and seasons where biomass burning is known to take place. A similar pattern of

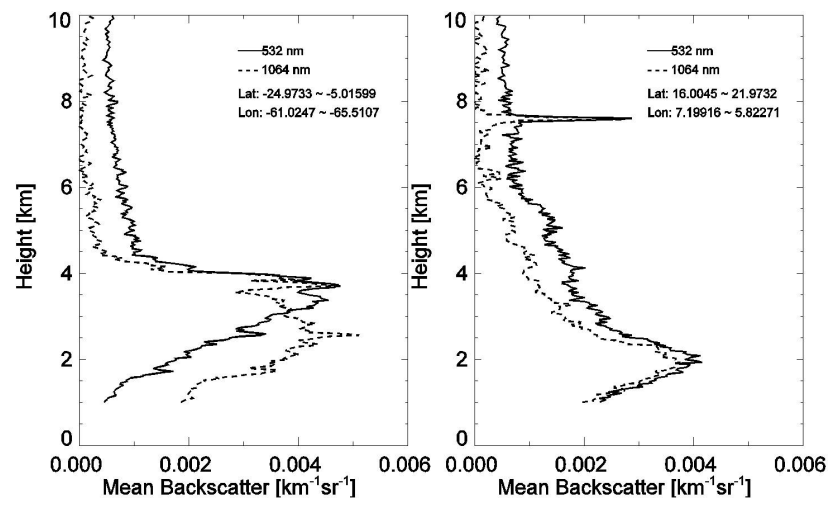

Fig. 4. CALIOP-measured attenuated backscatter profiles at $532 \mathrm{~nm}$ (solid line) at $1064 \mathrm{~nm}$ (dotted line) over Amazonia (left) and the Sahara (right).

apparent $532 \mathrm{~nm}$ sensitivity loss is also observed for carbonaceous aerosol layers above altostratus clouds. The apparent loss of sensitivity of the CALIOP $532 \mathrm{~nm}$ channel in comparison to similar measurements by the High Spectral Resolution Lidar (Hair et al., 2008), was observed in the presence of carbonaceous aerosols during a Canadian boreal fire event in 2007 (Kacenelenbogen et al., 2011). A possible explanation of the reduced signal in the presence of carbonaceous particles is the effect of aerosol absorption that, at the typically large optical depth values of smoke layers, would yield large aerosol absorption optical depths that significantly reduce the number of backscattered photons (A. Omar, personal communication, 2013). If low-level aerosols are not accounted for, the derived mean aerosol layer altitude would be biased high. For that reason, in this analysis we use CALIOP's $1064 \mathrm{~nm}$ measurements that are sensitive to the presence of carbonaceous and desert dust aerosols all the way down to the surface.

\subsection{Aerosol layer height calculation}

In reducing the CALIOP measured profiles, it was assumed that the vertical structure of the tropospheric aerosol load can be represented as a single layer. This assumption seeks to facilitate the use of the resulting climatology as input to global retrieval algorithms. Although, multiple aerosol layers are common, elevated dust or carbonaceous particles are most frequently observed as single layers. The parameter $Z_{\text {aer }}$ was calculated as the attenuated-backscatter-weighted height according to the expression

$Z_{\mathrm{aer}}=\sum_{i-1}^{n} H(i)\left[\frac{B_{\mathrm{sc}}(i)}{\sum_{i=1}^{n} B_{\mathrm{sc}}(i)}\right]$,

where $B_{\mathrm{sc}}(i)$, is the attenuated backscatter at height $H(i)$, and $n$ is the number of layers between the surface and $10 \mathrm{~km}$. 
The resulting aerosol layer height was assumed to be representative of the aerosol layer altitude at the OCCP. The information on aerosol layer height at the fine CALIOP resolution was propagated a few hundred meters beyond the OCCP. The aerosol layer height at the OCCP was also assumed to be representative of the aerosol altitude at any pixel in the nineOMI-pixel subset (i.e., within approximately $100 \mathrm{~km}$ of the OCCP in the same swath) if the presence of dust or smoke was detected according to the AI. By the same token, if for an OCCP pixel the CALIOP height was undetermined (due to excessive cloud contamination) but the AI on other nonOCCP pixels in the same swath indicated aerosol presence, the height for the corresponding pixel-position from the previous across-track scan was assumed if available. It should be emphasized that the resulting aerosol height data set is not a general representation of the altitude of all aerosol types but it is specifically designed to account for the height of elevated carbonaceous and desert dust aerosol layers when present.

Figure 5 shows three examples of the resulting aerosol layer height derived from $1064 \mathrm{~nm}$ CALIOP measurements as previously described. The solid line indicates the effective aerosol layer height calculated using eq. (1), and the dashed line represents the aerosol layer height assumed in the previous version of OMAERUV algorithm (Torres et al., 2007). CALIOP's observed vertical structure of the aerosol load on 4 April 2007 near the Bodele depression in the central Saharan shows the unmistakable signature of a rising column of dust between the surface and about $3 \mathrm{~km}$ at $16^{\circ} \mathrm{N} ; 12^{\circ} \mathrm{E}$ is shown in the top panel of Fig. 5. The airborne dust plume spreads north and south of the source in an atmospheric layer between 3 and $5 \mathrm{~km}$. The aerosol layer height assumed in the OMAERUV algorithm is underestimated by as much as $2 \mathrm{~km}$ in relation to that inferred from CALIOP observations.

The center panel illustrates the vertical structure of a smoke layer as seen by the CALIPSO lidar on 12 August 2006 over Angola and Namibia, and the southern Atlantic Ocean. CALIOP observations show the westward flow of smoke from fires in Angola and Namibia over the southern Atlantic Ocean. The CALIOP curtain image shows a southnorth transect of the smoke layer along the western coast of Central Africa from Angola, covering Angola's coastal waters $\left(\sim 12^{\circ} \mathrm{S} ; 13^{\circ} \mathrm{E}\right)$, and reaching land again over the Democratic Republic of the Congo's coastal area $\left(\sim 5^{\circ} \mathrm{S}\right.$, $11.5 \mathrm{E})$. Over the central and northern sections of the transect, the aerosol layer is clearly located above low clouds. The smoke layer over land generated from fires in Angola and Namibia occupies a $2.5 \mathrm{~km}$ thick layer that goes from the surface (about $1 \mathrm{~km}$ above sea level) to $3.5 \mathrm{~km}$ as indicated by the attenuated backscatter signal. The assumed aerosol layer height is consistently higher than the CALIOP derived value.

A layer of carbonaceous aerosols as seen by the OMI and CALIOP sensors over central Brazil on 30 September 2007 is depicted on the bottom panel of Fig. 5. The CALIOP curtain plot depicts the vertical structure of the layer over a region between $10^{\circ} \mathrm{S}$ and $30^{\circ} \mathrm{S}$ along CALIOPS's orbital track. On the northernmost end of the plume, the aerosol load is located in a $1 \mathrm{~km}$-thick layer between 3 and $4 \mathrm{~km}$ above the ground, and widens towards the south. In general, the assumed height is about $1 \mathrm{~km}$ higher than the CALIOP-based estimate.

\subsection{CALIOP-based aerosol height climatology}

The procedure described in the previous section to derive an effective aerosol layer height was applied to the global CALIOP record over the 30 month period from July 2006 to December 2008. The extension beyond 2008 was hindered by the loss of the OCCP resulting from the onset of the OMI row anomaly discussed in Sect. 2 . Gridded $1^{\circ} \times 1^{\circ}$ resolution monthly averages of ALH were calculated. A minimum of five data points per grid were required to produce a monthly value. Extracts from a degraded $5^{\circ} \times 5^{\circ}$ gridded product were used to fill gaps in the original $1^{\circ} \times 1^{\circ}$ product resulting from CALIOP's lack of global coverage and the interference of clouds. Additionally, image processing techniques using convolution and Gaussian smoothing (Gonzalez and Woods, 1992) were applied to reduce the noise and minimize the effect of isolated maxima and minima.

Figure 6 shows global maps of the monthly averaged aerosol layer height $\left(Z_{\mathrm{clp}}\right)$, in $\mathrm{km}$ above surface, derived from CALIOP observations. Maps shown correspond to the midseason months (January, April, July, October).

The $Z_{\mathrm{clp}}$ spatial distribution in January is dominated by the presence of desert dust and carbonaceous aerosols copiously produced by their emission sources in the Saharan (desert dust) and equatorial Africa (biomass burning). $Z_{\text {clp }}$ values between 3 and $4 \mathrm{~km}$ predominate over the northern African deserts, while values between 2 and $3 \mathrm{~km}$ are observed associated with the fire activity in the tropical belt along the Atlantic coast from Guinea to Nigeria, and extending eastwards to Ethiopia. Over the northern Atlantic Ocean, $Z_{\text {clp }}$ descends rapidly westwards from over $2 \mathrm{~km}$ at the North African west coast to the $45^{\circ} \mathrm{W}$ meridian, and continues to decrease, with some oscillations, to minimum values of about $1 \mathrm{~km}$ over the Gulf of Mexico. $Z_{\text {clp }}$ values around $3 \mathrm{~km}$ can be observed over the SE United States as a consequence of local fires, as well as long-range transport from Central America. High $Z_{\text {clp }}$ values are also observed in the Southern Hemisphere summer over the land masses of South America (Patagonia), West Africa, and Australia where desert dust production and smoke from brush fires (Australia) are commonly observed in January.

A significant narrowing in the $Z_{\text {clp }}$ north-south distribution over the Atlantic Ocean is apparent in April following the conclusion of the equatorial Africa biomass-burning season. $Z_{\text {clp }}$ values higher than those observed in winter are apparent over the Atlantic Ocean owing to the spring activation of Saharan dust sources. Elevated layers $(3 \mathrm{~km}$ and higher) can be observed over the eastern half of the continental US, generally resulting from the transport of carbonaceous aerosols from boreal wildfires in Canada (northeast) 

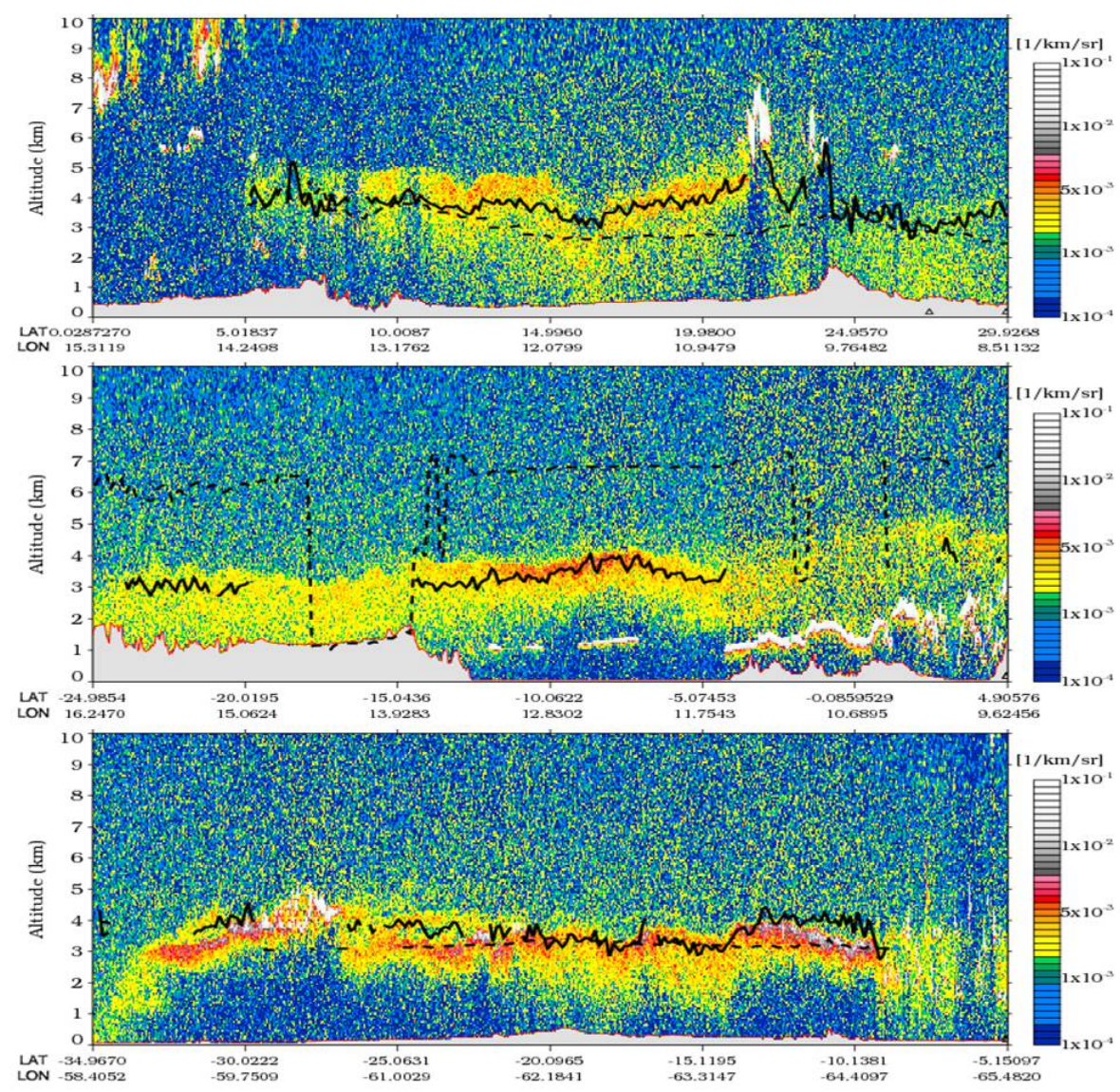

Fig. 5. CALIOP-measured $1064 \mathrm{~nm}$ backscatter profiles for three aerosol events: desert dust layer over central Saharan (top); smoke layer over Angola and Namibia (middle); smoke layer over central Brazil (bottom). CALIOP-based (solid line) and previously assumed (dashed line) aerosol layer heights are shown.

and local sources, as well as contribution from transport from Mexico and Central America (southeast). The observed $Z_{\text {clp }}$ values lower than $3 \mathrm{~km}$ over the western half of the US are likely associated with local dust production. As a consequence of the activation of dust sources in Central Asia, elevated layers (3 km and higher) are apparent over Afghanistan, Turkmenistan, and Uzbekistan. Longrange transport of desert dust from the Saharan sources across the Mediterranean, and from sources in Central Asia trigger the spread of dust aerosol layers about $2.5 \mathrm{~km}$ high over western and northern Europe. Eastward transport of desert dust following the spring activation of the Gobi and Taklamakan deserts, and layers of carbonaceous aerosols from biomass burning in Southeast Asia linger over East Asia in layers 2 to $3 \mathrm{~km}$ high.

An enhanced July $Z_{\text {clp }}$, associated with the northward spread of aerosol layers from boreal fires in Canada and Siberia, is observed at about $3 \mathrm{~km}$ over northern Canada and the Arctic. The summer Saharan aerosol layer over the Atlantic Ocean between $10^{\circ} \mathrm{N}$ and $30^{\circ} \mathrm{N}$ varies in altitude between $3.5-4.0 \mathrm{~km}$ at the west coast of North Africa going down towards the west, reaching $1.5 \mathrm{~km}$ over the Gulf of Mexico. Smoke from biomass-burning activity in Central Africa spills over the southern Atlantic Ocean in an aerosol layer at $2-2.5 \mathrm{~km}$.

The October global aerosol height distribution is characterized by an overall $Z_{\text {clp }}$ decrease. Except for a height increase over the biomass-burning regions in the Southern Hemisphere, autumn $Z_{\text {clp }}$ values are lower than the previous season values by $1-2 \mathrm{~km}$ over most of the globe. The Saharan layer $Z_{\text {clp }}$ over the Atlantic Ocean reaches values as low as $1.5 \mathrm{~km}$ about halfway between North Africa and the Gulf of Mexico. The carbonaceous aerosol layer, known as the "river of smoke", flowing off Southeast Africa along the Indian Ocean at a $1-2 \mathrm{~km}$ height $Z_{\text {clp }}$ is clearly observed.

A global three-dimensional representation of the atmospheric aerosol load from multi-year CALIOP observations has recently been made available (Winker et al., 2013). A global seasonal description of aerosol height is presented in Fig. 9 of Winker et al. (2013), defined as the altitude at which $63 \%$ of the AOD lies below $\left(H_{63}\right)$. Although the major features of the global absorbing aerosol load shown in Fig. 6 (e.g. Saharan dust layer between $2-4 \mathrm{~km}$ in summer and much lower in spring and fall; elevated fall smoke layer 


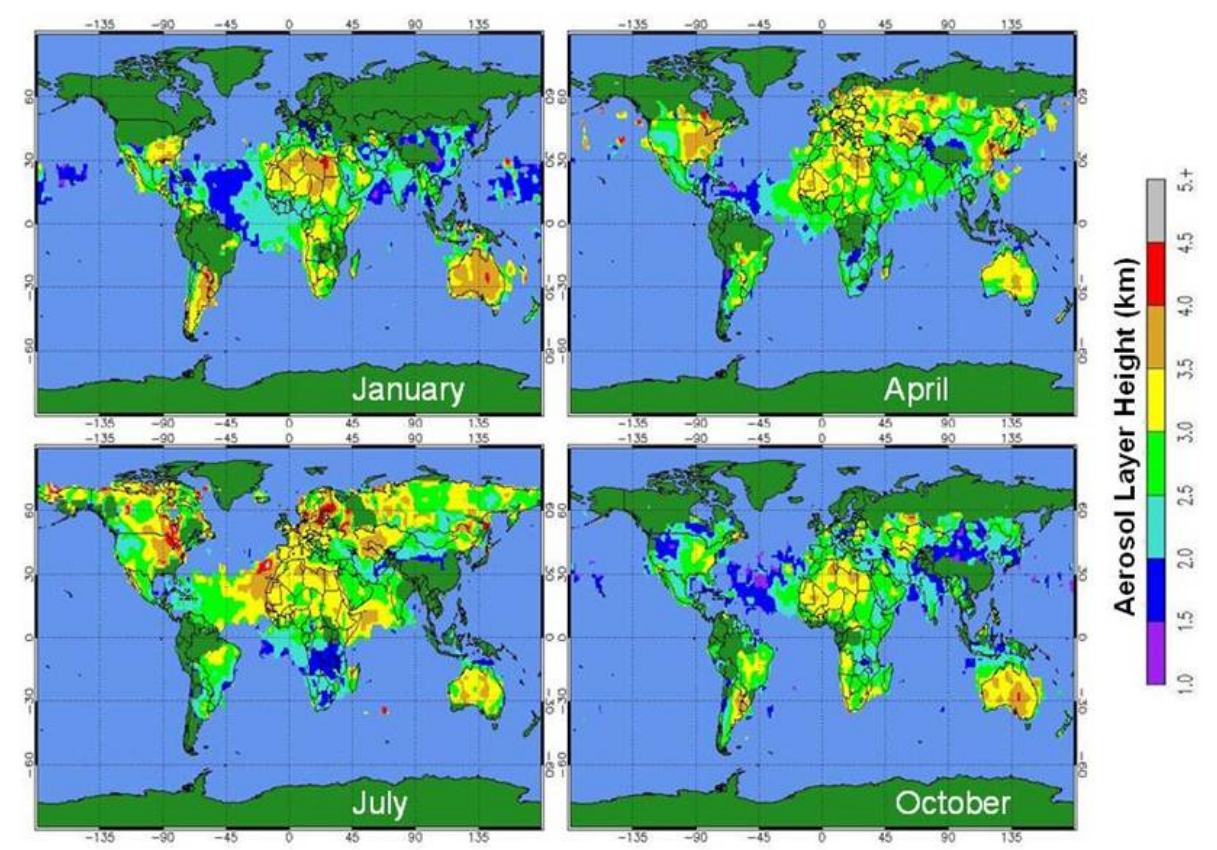

Fig. 6. Monthly average aerosol layer height.

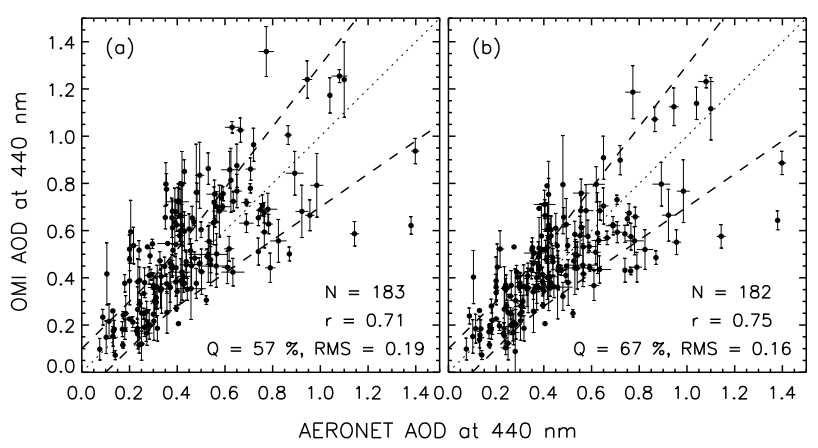

Fig. 7. Evaluation of AOD retrieval using standard aerosol layer height assumption (left) and CALIOP climatology (right) at the Banizoumbou site.

over the South Atlantic) can also be identified in Winker et al. (2013), a direct comparison between the two products is not meaningful as they are essentially a representation of different aspects of the aerosol vertical distribution. The $H_{63}$ parameter represents the height at which about two thirds of the total aerosol load lies below, whereas $Z_{\text {clp }}$ is a measure of the level of peak absorbing aerosol concentration. The $H_{63}$ value is calculated including all aerosol types, whereas $Z_{\text {clp }}$ was specifically designed to capture the height of absorbing aerosol layers. Other important differences include time of observation (nighttime for $H_{63}$ and daytime for $Z_{\text {clp }}$ ) as well as different wavelength which, as discussed in this work, may produce different height results in the presence of carbonaceous aerosols.

\section{Evaluation of improvements in OMAERUV retrievals}

A brief discussion of the effect of the algorithm upgrades on retrieved products is presented here. Comprehensive assessments of the OMAERUV products using ground-based and other satellite observations are discussed in detail by Ahn et al. (2013) and Jethva et al. (2013).

The effect of using the CALIOP $Z_{\text {clp }}$ climatology as input in the OMI inversion algorithm was evaluated by comparing the optical depth from the OMAERUV algorithm to AERONET observations (Holben et al., 1998) using both the standard algorithm aerosol height assumption and the aerosol altitude extracted from the CALIOP climatology described here. The assessment exercise was carried out using AERONET measurements at the five sites listed in Table 1 , where the presence of elevated dust and smoke layers is routinely observed. OMAERUV AOD retrievals within a radius of $40 \mathrm{~km}$ of the AERONET site were compared to ground-based observations within a \pm 10 min window (Ahn et al., 2013). Columns 4 through 8 in Table 1 show respectively the resulting correlation coefficient $(r)$, intercept, the rms, and the number of retrievals within $10 \%\left(Q_{10}\right)$ and $30 \%\left(Q_{30}\right)$ of the AERONET values, for both the standard aerosol layer height assumption, and the CALIOP provided height information. The standard OMAERUV method of prescribing aerosol layer height of desert dust layers based on a model-generated climatology works fairly well as indicated the correlation coefficients between 0.71 and 0.83 at the five locations. A small but important improvement in these statistics is obtained when the CALIOP-based climatology of aerosol layer height is used. The CALIOP-based 
Table 1. Summary statistics of OMAERUV and AERONET aerosol optical depth comparison.

\begin{tabular}{lrrccccc}
\hline $\begin{array}{l}\text { AERONET } \\
\text { Site }\end{array}$ & $\begin{array}{r}\text { Location } \\
\text { Lat. Lon. }\end{array}$ & $\begin{array}{r}\text { Number } \\
\text { points }\end{array}$ & $\begin{array}{c}R \\
\text { Std Cal }\end{array}$ & $\begin{array}{c}\text { Intercept } \\
\text { Std. Cal }\end{array}$ & $\begin{array}{c}\text { RMS } \\
\text { Std. Cal }\end{array}$ & $\begin{array}{c}Q_{10} \\
\text { Std Cal }\end{array}$ & $\begin{array}{c}Q_{30} \\
\text { Std Cal }\end{array}$ \\
\hline Agoufou & $15.3 \mathrm{~N} ; 1.5 \mathrm{E}$ & 184 & 0.820 .83 & 0.130 .10 & 0.170 .16 & 5058 & 6471 \\
Tamanrasset & $22.8 \mathrm{~N} ; 5.5 \mathrm{E}$ & 98 & 0.830 .84 & 0.090 .08 & 0.100 .10 & 6063 & 6669 \\
Banizombou & $13.5 \mathrm{~N} ; 2.7 \mathrm{E}$ & 182 & 0.710 .75 & 0.210 .17 & 0.190 .16 & 4553 & 5767 \\
Dakar & $14.4 \mathrm{~N} ; 17.0 \mathrm{~W}$ & 163 & 0.730 .74 & 0.140 .12 & 0.190 .15 & 3956 & 5869 \\
IER_Cinzana & $13.3 \mathrm{~N} ; 5.9 \mathrm{~W}$ & 118 & 0.790 .83 & 0.090 .08 & 0.210 .17 & 3547 & 5060 \\
\hline
\end{tabular}

(o)

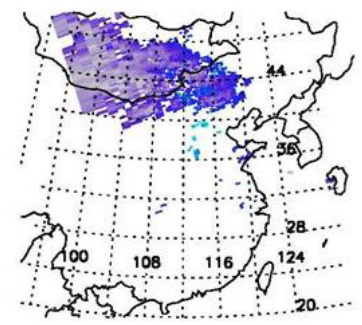

(c)

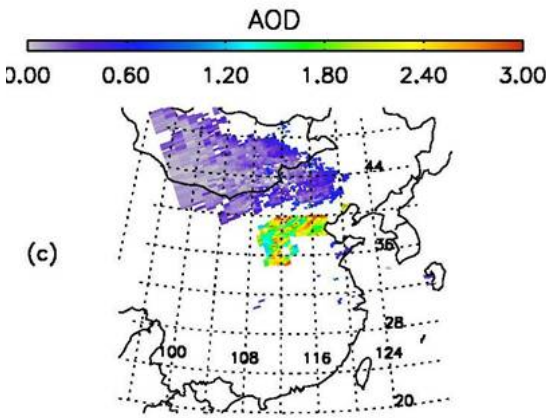

(b)
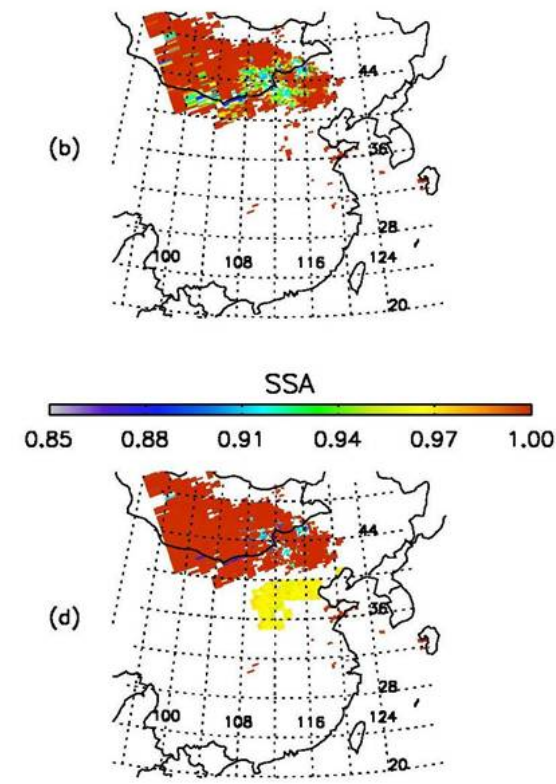

Fig. 8. Retrieved AOD and SSA at $388 \mathrm{~nm}$ from the previous (a, b) and improved (c, d) OMI UV algorithm over northeastern China on 20 August 2007.

approach yields higher correlation coefficients (between 0.74 and 0.84 ) and slightly smaller intercepts. The improvement is noticeable in terms of the $Q_{10}$ and $Q_{30}$ parameters, defined as the number of points (in percent) within $10 \%$ and $30 \%$ of the ground truth observations. $Q_{10}$ went up between 3 and $17 \%$ at the five sites whereas $Q_{30}$ increased between $3 \%$ and $11 \%$. In most cases the effect of using the CALIOPbased aerosol layer height was to reduce AERONET-OMI differences in the winter season when the aerosol layer height is underestimated by the standard assumption. The observed improvement is smallest in the middle of the Saharan (Tamanrasset site) and increases rapidly away from the dust aerosol source areas with the largest improvement registered at Dakar. The scatter plot in Fig. 7 illustrates the resulting OMAERUV AOD improvement in relation to AERONET observations at the Banizoumbou AERONET site.

As illustrated in Fig. 3, the use of $\mathrm{CO}$ measurements as an aerosol tracer has facilitated the identification of carbonaceous aerosols over arid regions, where the distinction be- tween dust and smoke particles would not have been possible without the availability of $\mathrm{CO}$ observations. The AIRS CO data has also enabled the detectability and characterization of high levels of boundary layer pollution aerosols undetectable by the previous OMAERUV algorithm without the help of AIRS CO data. Figure 8 depicts the retrieved fields of aerosol optical and single scattering albedo on $20 \mathrm{Au}-$ gust 2007 over northeastern China by the previous (top) and current (bottom) versions of the algorithm. Previously undetected aerosol load (AOD > 1.0, SSA 0.97) is apparent over Beijing, extending over a large area west and southwest of the city. These are likely pollution aerosols in the boundary layer.

\section{Summary and conclusions}

We have documented the use of CALIOP aerosol vertical distribution information and AIRS CO column amounts to provide information on aerosol layer height and aerosol type necessary for the retrieval of AOD and SSA by the 
OMAERUV algorithm. The combined use in real time of observations from OMI and AIRS on two different satellites is only possible thanks to the near-simultaneity of A-train observations.

It has been shown that the combined use of AIRS CO observations and the OMI UV aerosol index provides a way of reliably identifying the absorbing aerosol type when absorbing aerosols have been positively detected via the AI. Because $\mathrm{CO}$ is an excellent tracer of carbonaceous aerosols, elevated values of both $\mathrm{AI}$ and $\mathrm{CO}$ correspond in most cases to the presence of smoke layers, whereas the occurrence of high $\mathrm{AI}$ values and low $\mathrm{CO}$ amounts are associated with layers of desert dust aerosols. Another useful application of the AIRS $\mathrm{CO}$ data is the identification of high boundary layer aerosol loads that would otherwise be dismissed as cloud contamination by OMAERUV. Because of the large aerosol load associated with these events over biomass-burning regions and eastern China, it is possible to retrieve both aerosol optical depth and single scattering albedo.

We made use of time- and space-collocated CALIOP and OMI observations for the determination of the height of elevated layers of carbonaceous and desert dust aerosols detected by OMI's near-UV observations. An effective aerosol layer height was calculated as the attenuated-backscatterweighted average height obtained from CALIOP's $1064 \mathrm{~nm}$ measurements. Observations at $1064 \mathrm{~nm}$ were chosen over the $532 \mathrm{~nm}$ measurements because of apparent saturation effects at the shorter wavelength. The OMI-CALIOP combined analysis was carried out over a 30-month record from July 2006 to December 2008. In early 2009 instrumental issues affecting the OMI sensor resulted in the loss of the collocation capability.

A 30-month climatology of aerosol layer height was calculated. The impact of using CALIOP-based climatology of aerosol layer height was evaluated by comparing OMIretrieved AODs to AERONET observations at a number of locations in North Africa. Validation results indicate that although previous algorithm assumptions on aerosol layer height worked reasonably well, the use of the CALIOPbased climatology produces a noticeable improvement of retrieval results. The CALIOP-based absorbing aerosol layer height climatology and the real-time use of AIRS CO observations have been integrated into the current version of the OMAERUV algorithm.

Acknowledgements. We thank the AIRS and CALIOP projects for producing and making available the data sets used in this analysis. We also thank the AERONET project and the Principal Investigators of the sites used in this work. We gratefully acknowledge the anonymous reviewers whose feedback contributed to improve the manuscript.

Edited by: A. Kokhanovsky

\section{References}

Ahn, C., Torres, O., and Jethva, H.: Assessment of OMI near UV Aerosol Optical Depth over Land, J. Geophys. Res., submitted, 2013.

Ahn C., Torres, O., and Bhartia, P. K.: Comparison of OMI UV Aerosol Products with Aqua-MODIS and MISR observations in 2006, J. Geophys. Res, 113, D16S27, doi:10.1029/2007JD008832, 2008.

Anderson, T. L., Charlson, R. J., Bellouin, N., Boucher, O. , Chin, M., Christopher, S. A., Haywood, J. , Kaufman Y. J., Kinne, S., Ogren, J. A., Remer, L. A., Takemura, T., Tanre, D., Torres, O., Trepte, C. R., Wielicki, B. A., Winker, D. M., and Yu, H.: Am "A-Train" Strategy for Quantifying Direct Climate Forcing by Anthropogenic Aerosols, Bull. Amer. Met. Soc., 86, 1795-1809, doi:10.1175/BAMS-86-12-1795, 2005.

Andreae, M. O., Anderson, B. E., Blake, D. R., Bradshaw, J. D., Collins, J. E., Gregory, G. L., Sachse, G. W., and Shipham, M. C.: Influence of plumes from biomass burning on atmospheric chemistry over the equatorial and tropical South Atlantic during CITE 3, J. Geophys. Res., 99, 12793-12808, 1994.

Andreae, M. O. and Metlet, P.: Emission of trace gases and aerosols from biomass burning, Global Biogeochem. Cy., 15, 955-966, 2001.

Angstrom, A.: On the atmospheric transmission of Sun radiation and on dust in the air, Geogr. Ann., 12, 130-159, 1929.

Aumann, H. H., Chahine, M. T., Gautier, C., Goldberg, M. D., Kalnay, E., McMillin, L. M., Revercomb, H., Rosenkranz, P. W., Smith, W. L., Staelin, D. H., Strow, L. L., and Susskind, J.: AIRS/AMSU/HSB on the Aqua mission, Design, science objectives, data products, and processing systems, IEEE Trans. Geosci. Remote Sens., 41, 253-264, 2003.

Chahine, M. T.: Remote sounding of cloudy atmospheres, I, The single cloud layer, J. Atmos. Sci., 31, 233-243, 1974.

Chen, Z., Torres, O., McCormick, M. P., Smith, W., and Ahn, C.: Comparative study of aerosol and cloud detected by CALIPSO and OMI, Atmos. Environ., 51, 187-195, 2012.

De Graaf, M., Stammes, P., Torres, O., and Koelemeijer, R. B. A.: Absorbing Aerosol Index: Sensitivity Analysis, Application to GOME and Comparison with TOMS, J. Geophys. Res., 110, D01201, doi:10.1029/2004JD005178, 2005a.

De Graaf, M. and Stammes, P.: SCIAMACHY Absorbing Aerosol Index - calibration issues and global results from 2002-2004, Atmos. Chem. Phys., 5, 2385-2394, doi:10.5194/acp-5-2385-2005, 2005.

Penning de Vries, M. J. M., Beirle, S., and Wagner, T.: UV Aerosol Indices from SCIAMACHY: introducing the SCattering Index (SCI), Atmos. Chem. Phys., 9, 9555-9567, doi:10.5194/acp-99555-2009, 2009.

Dirksen, R. J., Folkert Boersma, K., de Laat, J., Stammes, P., van der Werf, G. R., Val Martin, M., and Kelder, H. M.: An aerosol boomerang: Rapid around-the-world transport of smoke from the December 2006 Australian forest fires observed from space, J. Geophys. Res., 114, D21201, doi:10.1029/2009JD012360, 2009.

Dubovik, O., Holben, B., Eck, T. F., Smirnov, A., Kaufman, Y. J., King, M. D., Tanre, D., and Slutsker, I.: Variability of absorption and optical properties of key aerosol types observed in worldwide locations, J. Atm. Sci., 59, 590-608, 2002.

Eck, T. F., Holben, B. N., Reid, J. S., Dubovik, O., Smirnov, A., O’Neill, N. T, Slutsker, I., and Kinne, S.: Wavelength dependence 
of the optical depth of biomass burning, urban and desert dust aerosols, J. Geophys. Res., 104, 31333-31349, 1999.

Edwards D. P., Emmons, L. K., Hauglustaine, D. A., Chu, D. A., Gille, J. C., Kaufman, Y. J., Petron, G., Yurganov, L. N., Giglio, L., Deeter, M. N., Yudin, V., Ziskin, D. C., Warner, J., Lamarque, J. F., Francis, G. L., Ho, S. P., Mao, D., Chen, J., Grechko, E. I., and Drummond, J. R.: Observations of carbon monoxide and aerosols from the Terra satellite: Northern Hemisphere variability, J. Geophys. Res., 109, D24202, doi:10.1029/2004JD004727, 2004.

Edwards, D. P., Emmons, L. K., Gille, J. C., Chu, A., Attie, J.-L., Giglio, L., Wood, S. W., Haywood, J., Deeter, M. N., Massie, S. T., Ziskin, D. C., and Drummond, J. R.: Satelliteobserved pollution from Southern Hemisphere biomass burning, J. Geophys. Res., 111, D14312, doi:10.1029/2005JD006655, 2006.

Ginoux, P., Chin, M., Tegen, I., Prospero, J. M., Holben, B., Dubovik, O., and Lin, S.-J.: Sources and distributions of dust aerosols simulated with the GOCART model, J. Geophys. Res., 106, 20255-20273, doi:10.1029/2000JD000053, 2001.

Gleason, J., Hsu, N.C., and Torres, O.: Biomass burning smoke measured using backscattered ultraviolet radiation: SCARB and Brazilian smoke inter annual variability, J. Geophys Res., 103, 31969-31978, 1998.

Gonzalez, R. and Woods, R.: Digital Image Processing, AddisonWesley Publishing Company, 192 pp., 1992.

Hair, J. W., Hostetler, C. A., Cook, A. L., Harper, D. B., Ferrare, R. A., Mack, T. L., Welch, W., Isquierdo, L. R., and Hovis, F. E.: Airborne high spectral resolution lidar for profiling aerosol optical properties, Appl. Optics, 47, 6734-6752, doi:10.1364/AO.47.006734, 2008

Herman, J. R., Bhartia, P. K., Torres, O., Hsu, C., Seftor, C., and Celarier, E.: Global Distribution of UVabsorbing Aerosols From Nimbus7/TOMS data, J. Geophys. Res., 102, 16911-16922, 1997.

Herman, J. R., and Celarier, E.: Earth surface reflectivity climatology at 340 and $380 \mathrm{~nm}$ from TOMS data, J. Geophys. Res., 102, 28003-28011, 1997.

Holben, B. N., Eck, T. F., Slutsker, I., Tanre, D., Buis, J. P., Setzer, A., Vermote, E., Reagan, J. A., Kaufman, Y. J., Nakajima, T., Lavenu, F., Jankowiak I.,, and Smirnov, A.: AERONET - A federated instrument network and data archive for aerosol characterization, Remote Sens. Environ., 66, 1-16, 1998.

Hsu, N. C., Herman, J. R., Bhartia, P. K., Seftor, C. J., Thompson, A.M., Gleason, J. F., Eck, T. F., and Holben, B. N.: Detection of biomass burning smoke from TOMS measurements, Geophys. Res. Lett., 23, 745-748, 1996.

Jethva, H., Torres, O., and Ahn, C.: Global Assessment of OMI Aerosol Single-scattering Albedo in Relation to Ground-based AERONET Inversion, J. Geophys. Res., submitted, 2013.

Jethva, H. and Torres, O.: Satellite-based evidence of wavelengthdependent aerosol absorption in biomass burning smoke inferred from Ozone Monitoring Instrument, Atmos. Chem. Phys., 11, 10541-10551, doi:10.5194/acp-11-10541-2011, 2011.

Kacenelenbogen, M., Vaughan, M. A., Redemann, J., Hoff, R. M., Rogers, R. R., Ferrare, R. A., Russell, P. B., Hostetler, C. A., Hair, J. W., and Holben, B. N.: An accuracy assessment of the CALIOP/CALIPSO version 2/version 3 daytime aerosol extinction product based on a detailed multi-sensor, multi-platform case study, Atmos. Chem. Phys., 11, 3981-4000, doi:10.5194/acp-11-3981-2011, 2011.

Levelt, P. F., Hilsenrath, E., Leppelmeier, G. W., van den Ooord, G. H. J., Bhartia, P. K., Taminnen, J., de Haan, J. F., and Veefkind, J. P.: Science objectives of the Ozone Monitoring Instrument, IEEE Trans. Geosci. Remote Sens., 44, 1093-1101, 2006.

Levy, R. C., Remer, L. A., Kleidman, R. G., Mattoo, S., Ichoku, C., Kahn, R., and Eck, T. F.: Global evaluation of the Collection 5 MODIS dark-target aerosol products over land, Atmos. Chem. Phys., 10, 10399-10420, doi:10.5194/acp-10-10399-2010, 2010.

Loveland, T. R., Reed, B. C., Brown, J. F., Ohlen, D. O., Zhu, Z., Yang, L., and Merchant, J. W.: Development of a global land cover characteristics database and IGBP DISCover from $1 \mathrm{~km}$ AVHRR data. Int. J. Remote Sens., 21, 1303-1330, 2000.

Luo, M., Boxe, C., Jiang, J., Nassar, R., and Livesey, N.: Interpretation of Aura satellite observations of $\mathrm{CO}$ and aerosol index related to the December 2006 Australia fires, Remote Sens. Environ., 114, 2853-2862, 2010.

McMillan, W. W., Barnet, C., Strow, L., Chahine, M. T., McCourt, M. L., Warner, J. X., Novelli, P. C., Korontzi, S., Maddy, E. S., and Datta, S.: Daily global maps of carbon monoxide from NASA's Atmospheric Infrared Sounder, Geophys. Res. Lett., 32, L11801, doi:10.1029/2004GL021821, 2005.

Pan, L., Guille, J. C., Edwards, D. P., and Bailey, P. L.: Retrieval of tropospheric carbon monoxide for the MOPITT experiment, J. Geophys. Res., 103, 32277-32290, 1998.

Savtchenko A., Kummerer, R., Smith, P., Gopalan, A., Kempler, S., and Leptoukh, G., A-Train Data Depot: Bringing Atmospheric Measurements Together, IEEE Trans. Geos. Rem. Sens., 46, 2788-2795, 2008.

Seftor, C. J., Hsu, N. C., Herman, J. R., Bhartia, P. K., Torres, O., Rose, W. I., Schneider, D. J., and Krotkov, N.: Detection of volcanic ash clouds from Nimbus7/total ozone mapping spectrometer, J. Geophys. Res., 102, 749-759, 1997.

Sinha, P., Hobbs, P. V., Yokelson, R. J., Bertschi, I. T., Blake, D. R., Simpson, I. J., Gao, S., Kirchstetter, T. W., and Novakov, T.: Emissions of trace gases and particles from savanna fires in southern Africa, J. Geophys. Res., 108, 8487, doi:10.1029/2002JD002325, 2003.

Susskind, J., Barnet, C. D., and Blaisdell, J. M.: Retrieval of atmospheric and surface parameters from AIRS/AMSU/HSB data in the presence of clouds, IEEE Trans. Geosci. Remote Sens., 41, 390-409, 2003.

Toledano, C., Wiegner, M., GROß, S., Freudenthaler, V., Gasteiger, J., Muller, D., Schladitz, A., Weinzierl, B., Torres, B., and O'Neill, N. T.: Optical properties of aerosol mixtures from sunsky radiometry during SAMUM-2, Tellus B, 63, 635-648, 2011.

Torres O., Bhartia, P. K., Herman, J. R., and Ahmad, Z.: Derivation of aerosol properties from satellite measurements of backscattered ultraviolet radiation. Theoretical Basis, J. Geophys. Res., 103, 17099-17110, 1998.

Torres, O., Bhartia, P. K., Herman, J. R., Syniuk, A., Ginoux, P., and Holben, B.: A long term record of aerosol optical depth from TOMS observations D and comparison to AERONET measurements, J. Atm. Sci., 59, 398-413, 2002.

Torres, O., Tanskanen, A., Veihelman, B., Ahn, C., Braak, R., Bhartia, P. K., Veefkind, P., and Levelt, P.: Aerosols and surface UV products from OMI Observations: an overview, J. Geophys. Res., 112, D24S47, doi:10.1029/2007JD008809, 2007. 
Turquety, S., Hurtmans, D., Hadji-Lazaro, J., Coheur, P.-F., Clerbaux, C., Josset, D., and Tsamalis, C.: Tracking the emission and transport of pollution from wildfires using the IASI CO retrievals: analysis of the summer 2007 Greek fires, Atmos. Chem. Phys., 9, 4897-4913, doi:10.5194/acp-9-4897-2009, 2009

Winker, D. M., Pelon, J., and McCormick, M. P.: "The CALIPSO mission: Spaceborne lidar for observation of aerosols and clouds", Proc. SPIE, 4893, 1-11 pp., 2003.

Winker, D. M., Tackett, J. L., Getzewich, B. J., Liu, Z., Vaughan, M. A., and Rogers, R. R.: The global 3-D distribution of tropospheric aerosols as characterized by CALIOP, Atmos. Chem. Phys., 13, 3345-3361, doi:10.5194/acp-13-3345-2013, 2013.

Witte, J. C., Douglass, A. R., da Silva, A., Torres, O., Levy, R., and Duncan, B. N.: NASA A-Train and Terra observations of the 2010 Russian wildfires, Atmos. Chem. Phys., 11, 9287-9301, doi:10.5194/acp-11-9287-2011, 2011.
Yokelson, R. J., Bertschi, I. T., Christian, T. J., Hobbs, P. V., Ward, D. E., and Hao, W. M.: Trace gas measurements in nascent, aged, and cloud-processed smoke from African savanna fires by airborne Fourier transform infrared spectroscopy (AFTIR), J. Geophys. Res., 108, 8478, doi:10.1029/2002JD002322, 2003.

Yurganov, L. N., McMillan, W. W., Dzhola, A. V., Grechko, E. I., Jones, N. B., and van der Werf, G. R.: Global AIRS and MOPITT CO measurements: Validation, comparison, and links to biomass burning variations and carbon cycle, J. Geophys. Res., 113, D09301, doi:10.1029/2007JD009229, 2008.

Yurganov, L., McMillan, W., Grechko, E., and Dzhola, A.: Analysis of global and regional $\mathrm{CO}$ burdens measured from space between 2000 and 2009 and validated by ground-based solar tracking spectrometers, Atmos. Chem. Phys., 10, 3479-3494, doi:10.5194/acp-10-3479-2010, 2010. 